\title{
Joint Participation of the State and Community Based Organizations (CBOS) In Poverty Alleviation: An Impact Study
}

\author{
Harrison Otuekong Ataide \\ Department Of Political Science/ Public Administration \\ Obong University, Akwa Ibom State, Nigeria
}

Received: Sep. 19, 2021 Accepted: Oct. 27, 2021 Online published: Nov. 22, 2021

doi:10.5296/jpag.v11i4.19239 URL: https://doi.org/10.5296/jpag.v11i4.19239

\begin{abstract}
The study was undertaken to examine the joint contributions of the state and Community Based Organisations (CBOs) in poverty alleviation and the impact thereof in Akwa Ibom State, Nigeria. The study adopted survey research methodology. The hypothesis of the study was set up to test the relationship between joint participation of the state and community based organizations (CBOs) in social infrastructural development and poverty alleviation. Simple random sampling and multi stage cluster sampling techniques were used to select the sample size for the study. The instrument for data collection was a 20 item, well validated questionnaire. The data analysis revealed that joint participation strategy of the state and CBOs has significant and positive relationship with poverty alleviation through the provision of social infrastructure such as water and electricity supply, skill acquisition, educational and health facilities in local communities of Akwa Ibom State. The study also revealed that the provision of such social infrastructure in the local communities through joint participation of state and CBOs enhanced establishment and spread of small scale business enterprises which in turn increased job opportunities and income earnings of the members of the communities under study. Based on the finding, the study recommends that the state should develop policies that would involve and integrate the people and their CBOs in the development of rural communities in Akwa Ibom State and Nigeria at large particularly in social infrastructural development for purposes of poverty alleviation in the state and the country as well.
\end{abstract}

Keywords: joint participation, community based organizations, poverty alleviation, infrastructural development

JEL Classification: M10, M14, O42 


\section{Introduction}

In Akwa Ibom State, poverty is rife and the need to enhance the living standard has become the greatest challenge facing the State today in terms of poverty reduction. Poverty is a plague that has been with Nigeria from its inception and its severity is worsening with time. It was reported as at 2006 that 66 percent of the population of Nigeria languished below poverty line (Agbor, 2006). This means that over 66 percent of Nigerians were unable to achieve normal life by then. Today, according to the Nigerian National Bureau of Statistics (NBS), in its "2019 Poverty and inequality in Nigeria" Report (2020) it is reported that in 2019 , more than 40 percent of the total population of Nigerians, almost 89 million people languish below the country's poverty line of 137,430 Naira (381.75 dollars) per year. This means that over 40 percent of Nigerians are unable to achieve normal life and that is a serious problem. In practical terms, many Nigerians can hardly feed themselves, the water taps are dry and as a result, water-borne diseases are now common place. Health services are completely beyond the reach of most people and education had gone beyond the income of parents. Large population of Nigerians, including those in Akwa Ibom State, in both urban and rural areas are striving to survive. Poverty has driven millions of rural inhabitants in Nigeria into the cities which are themselves on the verge of explosion in terms of over population and shortage of social infrastructure.

It is common knowledge that individuals all over the world have some fundamental needs and desires without which their existence would be unbearable. These life maintaining essential needs and desires comprise food, clothing, shelter, social security, and other social services. These are necessary conditions for the enhancement of life sustenance or the standard of living of the populace. This is what is generally referred to as development in real sense. According to Okereke (2004), development is better seen as enhancement in everyday comfort of most of the general populace through the provision of monetary and social foundations like commercial ventures, job, water, power and other essential services. The author further maintains that the major concern of most developing countries which include Nigeria, has been how to improve their societies and guarantee good life to their citizens by providing enabling environment that promotes development. He defines poverty as a condition of lack of the necessary resources needed to provide or procure those things that make for good living like good food, good health and good shelter.

Edame (2005) also opines that the increase per capital earnings, the abolition of utter lack and earnings disparity consequently comprise the required though not enough circumstances for growth. This fact was buttressed by World Bank Report on Human Growth (1994), which states that individuals are born with some latent competencies and opportunities. Thus, to achieve effective development in the developing countries, the State has to assume extensive role in the development process by adopting public administration through public service as an instrument for growth and development. The starting point in this direction should be a reconsideration of the two major strategies employed by the State that has dominated rural development landscape over decades in Nigeria. These two major prongs are: Government-led strategy and community-led strategy. A critical look at these two strategies invokes and brings to fore a third one that possesses the character of a synthesis of the first 
two. Ikeji, (2003) refers to this synthesized approach as integrative or co-operative strategy. According to this author, the major element in this approach is that community development is viewed as a joint business between government and the community. Effective co-operative participation between these two actors is the key concept and driving force in this strategy. For instance, both the state and the second actor, the community based organizations (CBOs) enter into a joint participation venture in the policy or programme planning, implementation, monitoring and evaluation leading to strategic outputs and outcomes that impact on the life of rural dwellers, particularly in poverty alleviation.

The integrative or participatory strategy in this work implies participation between the state and the communities through their Community Based Organizations (CBOs) at all levels of policy process in community development particularly with reference to poverty alleviation and availability of infrastructures like water and electricity, skill acquisition centers, education and health facilities and a host of other social infrastructural facilities. Twenty categories of community based organization (CBOs) identified in this study which are involved in community development in Akwa Ibom State through direct participation with the state government include the following: village associations; clan development unions; men social associations or societies; women social groups or associations; youth associations; men and women social organizations or associations; age grade associations; cooperative societies; market women associations; dealers on specific commodity associations; farmers associations; public works volunteer groups; trade guild associations; professionals associations; church or fellowship associations; community elders associations; thrift societies; parents teachers associations and ethnic nationalities.

All these associations or groups are domiciled within the various communities of Akwa Ibom State and are independent of government. They all have the central aim of developing their communities through the development of one purposeful community development project or the other. These organizations act as catalyst, mediators, pressure - groups and in some cases in the capacity of originating actors in social policy administration process. They take into consideration the impoverished nature of their communities and the poverty profile of the people in their communities and exert substantial influence on other actors in social policy administration particularly the State for the betterment of the condition of living of those in the rural communities. They join hands or partner with the State actor as non - State actor to bring about developmental projects in these communities.

These organizations see development of their communities as a process which includes a proper consideration of the fundamental challenges of their communities. They see this process as one for communal and practical actions by all concerned for the purposes of resolving the social challenges facing the people in their community. They combine assets from administrative and non-legislative agencies for successful developmental changes in their communities. They may or may not receive grants from international organizations or other agencies or the State but obviously they contribute among themselves within the community, their counterpart funding for joint projects with the state or other donor agencies. Development projects are thus funded from internal sources such as levies on members, voluntary donations, launching or appeal funds as well as matching grants from government 
(Emmanuel \& Muili, 2008). According to these scholars in a study they conducted on this, Community Based Organizations (CBOs) actually financed and executed development projects based on the need of their communities and their financial capabilities. They also found out in the study that Community Based Organizations (CBOs) had certain constraints such as inadequate funds for completing their development projects, lack of requisite technical manpower for capital intensive development projects and so on.

These constraints are checked and overcome by the existing social policy in Akwa Ibom State for counterpart funding for community development projects, particularly in the area of infrastructural development in local villages in the state. This is a policy akin to counterpart funding or what is generally termed matching grant often adopted by United Nations Development Project, UNDP and other international donor agencies. By this approach the state and community based organizations (CBOs) come together as co-actors to provide certain social infrastructural facilities such as water and electricity supply, school buildings, health centres, skill acquisition centres to the communities concerned. The communities through their community based organizations (CBOs) contribute 40 percent of the total cost of the development project. For instance, in rural electrification or water project, the 40 percent contribution in the execution of the project by the community is quantified and evaluated in terms of the electric poles and the land for the siting of the transformers as well as payment for meter connections, an equivalent of counterpart funding by the community. Government then provide as 40 percent contribution in the execution of the project the balance of 60 percent as matching grant for the project through award of contract for the purchase of transformers, wiring and connection to the national grid. On completion of the project, the community takes over the maintenance and management through their community based organizations (CBOs).

Electricity supply provided in this manner, that is through the joint participation of the state and the communities portends high level of success in rural communities than such effort being undertaken by government alone (Ajibesin, 2012). Same is applicable to the provisions of other social infrastructures in the rural communities with the overall advantage of financial and manpower constraints taken away. It must be noted here that before the introduction of the state and community based organizations (CBOs) joint participation strategy in Akwa Ibom State, it was all along government-led or community-led approach to community development that was prominent and prevalent in the rural communities in Akwa Ibom State and all rural areas of Nigeria. The rationale for adoption of the two approaches was diverse. For instance, World Bank (2000) observes that government-led strategy sees community occupants as being unequipped for normal arrangement, basic leadership and viable usage of projects of advancement because of their lack of modern development awareness.

But it must be pointed out that the adoption of government-led approach does not allow for participation of citizens in the advancement of their rural communities as they are alienated from the development process. Government provides what it deems necessary for the beneficiaries of the development projects and programmes and not what these target beneficiaries really need to raise their standard of living within their communities. Under the above circumstances, government assumes a leadership role and acts as the maker and 
implementer of rural development policies and programmes with the use of State structures and agencies, a top down approach to development. The philosophy behind the second approach, community-led strategy according to the World Bank (2006) is that rural advancement programmes are planned and executed primarily by the community for the advantage of the community. This is what is usually referred to as self-help approach which dominated the entire development scene in rural Akwa Ibom State communities and all over Nigeria from time immemorial.

The broad perspective of administering development particularly with regard to problems of policy implementation and the overall policy designs to meet development objectives before now had bugged the minds of policy administrators in Nigeria. Hence a new style for meeting development needs known as development administration was adopted in Nigeria for this purpose. According to Edame (2005), the term development administration was first used in 1955 by an Indian researcher called Goswami. The idea was utilized to separate the administrative system desired for developing countries and the traditional administrative system. The traditional administrative system generally concentrates on the preservation of law and order to guarantee a reasonable level of security within the community. Also, traditional administration is occupied with the provision of essential infrastructures like roads, pipe-borne water, electricity and schools.

Edame (2005) further asserts that the aim of development administration is to inspire innovation and change through accelerated growth. This is the same approach involved in the joint participation of the state and Community Based Organizations (CBOs) strategy in the acceleration of socio-economic development of the rural communities. Okereke (2004) argues that colonial administration in Nigeria was essentially based on the philosophy of maintaining law and order and that this was important since it was only in an atmosphere of peace that the colonial administration could successfully engage in production and exportation of raw materials for their factories in Britain. It is his contention also that there was no deliberate policy or policy development to industrialize Nigeria or provide the needed social and economic infrastructures, except when that enhanced the exploitation and exportation of the industrial raw materials back to their home countries. Thus, the only available public facilities such as electricity, water and good roads under colonial administration were restricted to specific areas that enhanced the attainment of the goals of the colonial administration. Social amenities like schools and hospitals were largely built by missionary organizations or groups. At independence according to Okereke (2003) the colonial administration bequeathed to Nigeria an underdeveloped economy and a social service that was virtually non-existent.

Instrument of social policy administration is employed through conscious effort to put in place social policies for addressing socio-economic problems inherent in the society. It is therefore, through the instrumentality of social policy administration that its principal actors provide specific social services to fill the gap between the deprived and the wealthy in the society. Social policies or social programmes or services such as provision of potable water, electricity supply, skill acquisition facilities and others in the society aim at reducing or alleviating poverty in such society. A survey by United Kingdom Department for 
International Development (DFID), (2000), revealed that two thirds of the Nigerian population exists under the poverty level. The report also showed that 85 percent of Nigeria's poor live in rural areas. In another report by DFID (2001), a study conducted in Nigeria, identified shortage of clean water, electricity, inadequate health care, lack of good roads, unemployment, among other social amenities, as the bane of underdevelopment and poverty in the rural communities in Nigeria.

Poverty can be seen from a monetary point of view as a circumstance of low pay and/or low utilization. It is this economic methodology that has regularly been utilized for building an imaginary index called neediness line, a line which separates the base estimations of pay or utilization important to buy the basic needs of life including standard of sustenance and different requirements of life (Obadan, 2002). Going by this, individuals are assumed be deprived when their deliberate needs in life, ascertained in terms of their livelihood or their utilization and desires, fall beneath the poverty line. Poverty line simply separates poor people, that is, those individuals who cannot bear the cost of the essential necessities of life from those that can afford normal livelihood. From the social viewpoint, poverty can be characterized as hardship, absence of access to education and so on. Consequently individuals are named poor because they cannot bear the cost of the essential needs of life, such as food, shelter and clothing as well as going through poor living conditions, Such poor conditions also include absence of employment opportunities, inadequate access to health care and other social amenities, and other circumstances that people are unable to realize their potentials and aspirations or generally deprived. In other words, poverty is the powerlessness to accomplish a basic way of life.

There is a noticeable trend of failure of past public policies and programme in addressing the intractable scourge of poverty in Akwa Ibom State. This situation created room for the introduction of the Joint Participation of the State and Community Based Organization (CBOs) in poverty alleviation as a way out. The coming of this new policy strategy brought elevated hopes and high expectations among the citizens of Akwa Ibom State. Years after the coming of this programme, there is general feeling among the people and informed observers that the available results offer little to cheer about. Critical opinions remain strident. They point out that there is little to show for the arguably huge resources thus far deployed into the programme. They call to question the appropriateness of the strategy. The strategy, many argue, has gone the same way as others that came before it. How founded are these fears? Has the strategy failed? If yes, why and how did it fail? These questions, and more, provide the basis for this study.

Therefore, the major concern of this work is how the problem of poverty in rural communities is addressed through the provision of these social infrastructures and services on the basis of joint participation of the state and the community based organizations in the local villages of Akwa Ibom State. For this reason, this study focused on determining the extent this strategy of Joint Participation in the provision of social infrastructures or services such as potable water, electricity supply, skills acquisition facilities impacted on poverty alleviation in Akwa Ibom State. It is in this view that the study sought to investigate the actual achievements or contributions of the joint participation between the two actors in social 
policy administration, the state and the community based organizations (CBOs) in the provision of infrastructural facilities as well as the cumulative effect or impact of this strategy on poverty alleviation in Akwa Ibom State of Nigeria.

\section{Literature Review}

This work primarily is centered on the issues of development and underdevelopment as well as modernization and social change in the rural communities as they relate to the provision and availability of social infrastructure for the overall development of these local communities for the betterment of the livelihood of the people in these communities. There has been a number of previous intellectual works forming a rich body of literature on the subject. Considerable numbers of these works dwell on the problems of rural underdevelopment and poverty generally including policy agenda aimed at addressing these problems. The core issue has always been the appalling state of infrastructure in the local communities and this is the bane of underdevelopment and high level of poverty in these rural communities.

According to World Bank in its Report (1996), an essential feature of the deprived citizenry in Nigeria is that they have a tendency to be gathered in poor groups and that such groups are distinctively cut off from the advantages of advancement by the nonappearance of social infrastructure. That Report states that, access to social services is a basic component in overcoming neediness and since destitution has a tendency to be amassed in poor groups, focused endeavours are required, both to prompt development and to give social administration the necessary foundation if the profundity and seriousness of destitution are to be lessened in all locales of nations. The Report goes further to state that development depends fundamentally on expanding access of the destitute individuals to quality social administration and key base with a specific end goal to empower them build their human capital and make full utilization of their principal resource, specifically their work. A look at existing literature in this area shows lack of consensus on the nature and dimensions of the problem of development or lack of it in the Third World countries, which include Nigeria, Akwa Ibom State being part of it. Expectedly, policy prescriptions and options among societies of these Third World countries, varied as they are, follow these varied and often conflicting positions. Undertaken here, is a review of some of these relevant works as it pertains to development and underdevelopment in relation to the problem of poverty.

The importance of development has advanced with time from its limited conceptualization in economic or monetary terms in relation to GDP or GNP to more expansive conceptualization as a multi-dimensional procedure including modifications in structures, states of mind and establishments and including economic or monetary development. In the search for a proper definition of the term development, Seers (1970) posed three basic questions: The things to ask around a nation's advancement are in this manner: what has been going on about poverty? What has been going on about unemployment? What has been happening to imbalance? The above attestation implies that any plan or strategy which possesses no objectives for diminishing destitution, unemployment and disparity can hardly be viewed as an advancement or development procedure. According to Seers (1970), advancement includes 
the formation of chances for the acknowledgment of human potentials. Seers assumed that people have certain essential necessities, which must be fulfilled. Among these are sufficient nourishment, something advantageous to do (occupation), and the disposal of the sorts of disparity, which lead to neediness.

\subsection{Community Development and Poverty Alleviation}

Community development is a procedure by which endeavours of individuals, groups, agencies or governments, or a combination of them are designed towards enabling communities to understand their potential, form self-capacity and live life of nobility and satisfaction evidenced in improved quality of life and standard of living. It leads to higher levels of civilization (Ake, 1996). This is by way of modernization. It also leads to control over productive forces because availability of basic infrastructures enhances higher productive capacity of citizens (Anikpo, 1984). Furthermore, it brings about reduction in the rate or incidence of poverty, unemployment and inequality (Seers, 1970). It also provides access to basic amenities such as electricity, potable water and so on. In addition, it leads to enhance educational opportunities and improved productivity (Onuaha, 1999).

In generic terms community development is divided into two groups, namely organic and mechanistic types of development (Strauss, 1953). Organic development is innate, self-propelled and natural. Thus rural growth can be viewed as a natural procedure in the sense that both urban and rural communities in Nigeria for example had been engaging in community development of their communities from their inception (Umoh, 1985). From the inception of the country, most communities in Nigeria provided themselves and are still doing so, with schools, health facilities, civic and skill acquisition facilities, community water and electricity projects through self-help, independent of the government. All these efforts is to improve their living conditions through communal effort. Thus, execution of development projects by these communities through self-effort are expressions of organic development.

On the other hand mechanistic type of community development depends on the principle of organic development which assumes that the people have ideas about their needs and wants (Wheeler, 1936). All they require is only to be given opportunity, guidance and motivation to cause them to develop themselves (Peet and Watts, 1996). Unlike organic development, mechanistic type of community development according to Familoni, (2002), Chino, (2004) and World Bank, (2004) is stirred up or generated from outside by a factor or an agent that is external to the community or if it is within the community, an urge or motivation which is particular to the sponsor or agent and strictly speaking non-communal.

There are also two variations of mechanistic community development, the public mechanistic type, sponsored by the government through authorized agencies and ministries and the private typology sponsored by individuals, such as social clubs or unions and corporate bodies on profit motives (Egun, 2010). In the case of public type, the project is planned, funded and executed as well as managed by government or its agencies. Community development should, apart from fulfilling the basic desires of the people, center on the development of communal spirit for initiating projects for the improvement of the wellbeing of the communities. Thus, cooperation between communities, the state and the industries 
should be encouraged to achieve such goal.

\subsection{Community Based Associations and Community Development}

It is to be noted here, that there has always been in existence in Nigerian communities, village associations, occupational associations and unions, age grade associations, social clubs, credit unions and religious groups which served as fora for collective decisions for community improvement (Warren et al, 1995), (CASSAD, 1992a). In Southern Nigeria, there had always existed a tradition of implementing socio-economic infrastructural development projects through self-help efforts (Adeboyejo, 2006). The various common interest groups, which exist in the communities to promote socio-economic and welfare of both the members as well as that of their community has been variously defined or designated as Community Development Associations (Oluwu et al, 1991), community based organizations (CASSAD 1992b). In this work, Community Based Organizations is adopted.

The literature on the subject is replete with empirical analysis of well-known pre-occupation of these organizations or associations as agents of community development (CASSAD 1992a, 1992b), (Aguda, 1998), (Oyegoke, 1998). Esulan and Uphoff (1984) see these community organizations as intermediaries of social change and in that wise, Kerr, (1978) opines that community organizations facilitate the process of transition of their traditional communities from traditionalism to modernity. Consequently they have been referred to as growth machines for their local communities (Barkan et al, 1991) or as shadow State which performs the duties of the State in the area of service delivery (Agunbiade, 1998), (Aguda, 1998), (Oyegoke, 1998).There has been recorded success stories of such associations in all parts of Nigeria. For instance, Egbe Omo Ibile in Awe and Fiditi in Oyo State (Mark, \& Titilola, 1998), Odimodi Ebiodou Bene of the Niger Delta Region (Ikporukpo, 1998). These indigenous organizations use their own resources from an exclusive membership based on certain criteria of indegeneity to secure their common welfare and mobilize resources for the development of their communities.

In Akwa Ibom State, these organizations exist in every rural community. As early as 1989, the State Government had recognized their immense contributions to community development in the State and the State government also realized that their major handicap was limited financial resources. A government policy of assisting these associations financially to put up community projects particularly in the area of social infrastructural development such as community electricity, water projects, schools, health and skill acquisition facilities etc. was put in place in that year. Community Associations by that policy are given "matching-grant" to subsidize the cost of such projects. The provision of these social infrastructures stimulates economic activities in the benefiting communities thereby bringing down the incidence of poverty in such communities. This approach has led to many rural communities in the State having cottage hospitals, schools, electricity, water works and processing mills. For instance there is no village in Itu Local Government Area of Akwa Ibom State that does not have electricity, most of which were connected to the National grid through this approach (Ikeji, \& Ataide, 2006).

This approach has also facilitated strong partnership relationship between the citizens and 
government. As Putnan, (1993) puts it, building and nurturing strong social associations among nationals and connections among people, state and non-legislative associations is a basic stride in enhancing the social fabric that undergirds open and private establishments in hearty majority rules systems and solid financial sector. According to Hesselbein et.al, (1998), this approach enables the citizens identify by themselves community problems, enter into partnership and develop and implement plans to address the problems of development in their communities. Here too, the people have direct stake in the programmes, even though they are executed in partnership with government.

In a study conducted in South Africa by Adam, Bell and Brown, (2002) on the importance of a similar grant policy for community development known as Community Partnership Grant (CPG) programme, it was found that various groups used the Community Partnership Grant programme to provide social infrastructure of varying forms in their communities. For example, with the community partnership grant programme, a group of beneficiaries built a village park in their area, a group of fathers built a local school and a volunteer group built a sewing centre for senior citizens in different communities in South Africa. Another major finding of the study was that the Community Partnership Grant programme created a financial base and partnership linkages that made it possible for citizens in South African communities including tribal village communities to design and implement social programmes and projects for the welfare of members of such communities and the overall development of their communities. This study is also significant in terms of its indication that such policy as the community partnership grant programme can aid the growth and development of rural communities in Nigeria as well.

\subsection{Strategies for Community Development}

There are obviously many ways to deal with rural advancement or development. There is a consensus among scholars such as, Obibuaka, (1973), Roa and Woolock, (2003), and Ikeji, (2003) that participatory approaches bring about success in the implementation of community programmes and projects. Participatory approaches to community development also tend to stimulate and sustain the interest of community development project beneficiaries, encourage community involvement and the use of local institutions. Participatory approaches also reflect the sensibility of the existing social organizations, traditions, values and culture of the intended beneficiaries (Obibuaka, 1993). Thus, Obibuaka in his study postulates that the populace are grateful for programmes that enhance their livelihood.

According to World Bank (2002), the overriding benefit of people participation in community based programmes leads to increased project effectiveness. Ntui (2005) on the other hand contends that lack of grassroots participation in programmes implementation leads to frustration and abandonment of such projects or programmes. Roa and Woodlock, (2003) in their study point out that when programmes for infrastructural development are considered, composed, arranged and undertaken by totally non-rural dwellers, there is an inclination with respect to the recipient to dismiss, overlook or abuse the subsequent output or infrastructure. Other proponents of this participatory development model, Uphoff and Esulan, (1997), Ostron, (1990), Sen, (1999), and Chambers, (1983), argue that participation of the community 
members in their development effort is a vital way of letting the community members take responsibility over the development of their communities. Participatory approach as opposed to top down development approach, which is disempowering and ineffective, anchor on an all-encompassing endeavour of inciting cooperation through institutions that compose deprived people and manufacture their capacities to act all in all to their greatest advantage. The community is involved in identification of community needs and subsequent project design and implementation.

Akin to the participatory development model is the grassroots association model deduced from Chambers, (1983) participatory model. This model conceives community participation as an active involvement in community development effort through traditional institutions and associations such as age grade, men and women groups, guilds and village unions. All these provide the people, platform for participation in the development process of their community. Ebong, (1991) opines that people re-orientation of all concerned traditional associations should be articulated into a functional chain (continuum) of awareness understanding - motivation - mobilization and participation. It is therefore clear that for effective implementation of community development projects, the people and beneficiaries of such projects must be included in the design and execution of the projects. In that wise, Huntington, (1968) rightly asserts that community development cannot succeed without the active participation of the community. Midgley et al, (2003) also state that development programmes and policies cannot just be evolved for rural people but rather must involve the people if they are to succeed.

According to Ikeji, (2003), strategy execution is about the most basic measurement in the strategy procedure, given the way that achievement or disappointment of any given arrangement is to a high degree, a component of execution. The requirement for successful execution strategies is accentuated. There is need for a dire and more appropriate one for the local communities where the personal satisfaction is wretchedly low as a result of a great extent of disregard and unfulfilling execution of most programmes. The author analyzes the dominant conceptual models and policies for executing local growth strategy such as; the state-led and rural-led and the third one as the integrative/cooperative strategy. In his extrapolation, he posits that government-led strategy (top-bottom model) or approach to policy process is the guiding principle and practice in government planning and that this means government working for the people without their inclusion in the process.

He concurs with World Bank (2000) that government assumes a leadership position and acts as originator and executor of rural development policies and programmes with the use of State apparatuses and agencies. He also maintains that a glance at all the Nigerian National Development Plans will provide evidence in support of this position. He enumerates, more handy examples of programmes in Nigeria pursued along the government-led or top-bottom policy strategy to include: the Operation Feed the Nation (OFN), National Accelerated Food Production Programme (NAFPP), River Basin and Rural Development Authority (RBRDA), Agricultural Development Project (ADP), Directorate for Food, Roads and Rural Infrastructure (DFRRI), and Petroleum Trust Fund (PTF) all of which made poor outing and history of failed programmes in Nigeria, in spite of the expected policy outcomes. He 
concludes that in principle, nothing is virtually wrong with government-led strategy but for the apparent faulty assumptions and perceptions of policy planners and makers.

\subsection{Community Participation in Community Development}

Involvement of local people in their own development has received increased acceptance, popularity and attention in the present century by developing countries than was the case many centuries ago. Also freedom of decision making at the local level is coming to be accepted in many countries as an important policy element. As in the characteristic of interpretations, participation has different appellations by its various users. In much development literature we frequently come across phrases such as mass participation, citizen participation, local participation, community participation, and popular participation, just to mention a few. However, regardless of the appellations and different devices adopted, the central aim or objective is always involving local people in rural community development programmes.

World Bank (2012) defines participation as dynamic inclusion of villages in need evaluation, ascertaining of needs strategy and commitment of potential recipients to the acknowledgment of the programmes for their own advancement. The World Bank Report (2012), emphasizes that rural based participatory methods that are employed to deal with rural development are portrayed as inevitable means for pro - needs schemes. The key element in participation is the fuse of neighborhood learning into ventures' basic leadership process. Participation is productive for supportable changes as a dynamic procedure by which recipients or customer bunches impact the bearing and improvement programmes with a specific end goal to upgrade their prosperity as far as salary, self-awareness, independence and other lofty qualities are concerned.

Abasiekong, (1999) opines that participation is viewed as an indicator of pluralism and as an instrument by which pluralism in a community may be measured. It includes playing a dynamic role in rural choices, enhancing information on rural challenges, participation at open gatherings, and related endeavours to impact proposed measures through people and group action. Abasiekong cites four case studies dealing with the present general overview of approaches to community participation and involvement. He points out as an example that; Community involvement in health care means more than public participation in carrying out campaigns or in constructing wells, latrines and health facilities. It means sharing the responsibility and participation actively in planning and organizing health services. It also includes the proper utilization of these services by the community. This approach implies that health problems cannot be solved by concentrating on health programmes to the exclusion of the socio-economic conditions and problems of the people. This scholar stresses that it is their health and well-being that are being discussed. He says that it is the attitudes, habits, or actions of the individual or of the family that promote or endanger their health and that such individual naturally will accept the treatment given and carry out any supplementary action after care or rehabilitation measure including those for the prevention of a relapse or of the spread of the diseases to others. This sequence of events occurs even in most villages. He adds that it is important that the members of the community be made responsible for deciding 
on their local health priorities, for planning and organizing the method of work, the level of renunciations, and the selection of training arrangements for additional community health workers as are deemed appropriate, and, for organizing self-help projects in relation to the provision of water supply, transport, road, electricity, and education facilities in the community. Abasiekong further identifies major concepts as representing the core of the contemporary conception of participation. These included: taking part in decision making; taking part in planning of rural development projects; taking part in the evaluation of the projects. Participation invariably implies many people working to achieve a common goal or objective. In rural communities cooperative effort cannot just be enacted by fiat by a development planner. There exists in each rural community already established patterns of associations beyond which cooperative activities cannot succeed. By consulting with potential rural participants, these traditional patterns of interactions can be discussed and used effectively to foster community participation and community development.

Fred, (2007) observes that participation of local dwellers in their own growth is important. Too often, decisions have been made that are unacceptable to the group whose interests are at stake. Since in the end, all changes depend upon the willingness and ability of the people to adopt innovations, their cooperation is vital. Participation through their social organizations does not only give people a chance to develop a feeling of need for the development programme, but also enables them to work out in their own way adjustments of the new programme to the pattern of their existing customary, cultural and traditional ways of life. No project that can affect the socio-economic life of any community can possibly succeed if the recipient communities do not participate in the evolution of such project, since ultimately it will be their responsibility to continue with it or to abandon it altogether. Fred concludes that for the success of any rural development programmes, community participation is very important, particularly in the utilization of the potential resources of the community. Tunrayo, (2009) cited a study carried out to examine the impact of community based organizations (CBOs). His study indicated that community based organizations (CBOs) are very essential in execution of community projects and that there is a positive relationship between socio-economic projects in rural communities and the level of poverty in such communities.

According to a study carried out by Emmanuel and Muili, (2008) to examine how community based associations are bridging the poverty gap in urban communities. Their study found that community based organizations are now vigorously involved in enhancing public infrastructure in urban communities to accommodate the influx of people migrating from rural communities into the already overpopulated urban communities with existing inadequate and dilapidated social infrastructures. The study concluded that mass mobilization of both human and material capital in project commencement, evaluation, execution of these projects was the cornerstone of this strategy. Their findings have far reaching and strategic suggestions for recommending community participation for socio economic development of the developing societies in terms of the socio political progression of the present society in third world countries such as Nigeria. Harnessing rural assets and coordinating community based associations and other non-governmental organizations into development process of the undeveloped and neglected communities of Akwa Ibom State and Nigeria at large may be the 
last hope of the masses for the better living standard since government capacity to develop the rural communities has greatly diminished especially in terms of providing the much needed social infrastructures in these communities.

\subsection{Social Infrastructural Development and Poverty Alleviation}

Social infrastructures are basic facilities that allow rural communities carry out industrial and manufacturing activities. Bhalla (2002) maintains that availability of social infrastructure in rural-communities aids socio-economic development and as such, substantial reduction of pervasive level of poverty in such rural communities. Aliu, (2001) points out that one of the factors that compound the rising incidence of poverty in Nigeria is social infrastructural deficiency. He names ineffective implementation of state programmes as another factor for rising incidence of poverty in Nigeria. He opines further that in order to mitigate the alarming poverty rate, the target should be enhancing rural development through joint participation of government and existing community organizations and civil society groups. It is therefore of prime importance to note that, the State should put in place strategies to foster the activities of community-based associations to provide social infrastructure at the grassroots level to achieve greater poverty reduction at that level.

According to Abumere et.al, (2002), any programme for poverty decrease cannot succeed unless upheld by social framework. This may be the reason Akinola, (1997) opines that the populace in the local communities are deprived due to basic necessary infrastructure. Burky, (1993) supports this view, according to him; poverty exists in the rural communities because of lack of infrastructure and modern techniques of agriculture. Perhaps this is why he identifies and measured poverty level of an area by the number and condition of infrastructural facilities in the area. In another dimension, Bhalla, (2002) shows how poverty is manifested in rural communities without adequate infrastructures such as portable water, clean environment, power and education facilities etc. He gives as an example that unsafe water and lack of clean environment increase the prevalence of water and airborne diseases. He states further that whenever such diseases attack the rural people, there is a drastic reduction in productivity and the resultant effect is poverty.

Fawehinmi, (2003) also asserts that there is no way a country can solve the interlocking problems of mass poverty, high commodity prices, food shortages and malnutrition without improving substantially on rural infrastructures which are the basis of increased productivity and quality of rural life. Social infrastructural development in itself reproduces economic enterprise. Hammer et.al, (2000) and Idachaba, (1985) posit that infrastructure constitute the substance of rural welfare and effort to raise rural welfare must necessarily embrace infrastructural facilities like electricity, pipe-borne water and even transport facilities.

According to Donald, (1972) and Frank Iseh, (2003), social infrastructure is the bedrock for improvement of rural communities for the achievement of the overall common social and economic objectives of such communities. Onokerhoraye and Okafor, (1994) in supporting this view add that the provision of social infrastructure in rural communities is of extreme necessity for improvement of the welfare and standard of living of the rural dwellers. Inadequate social infrastructure in rural areas has also been identified by Wimberly, (1993) as 
one of the most serious threats to social development in developing nations.

Akpama (2005) in his study found out that there is a positive correlation between energy production and economic expansion and growth. Specifically, he states that power supply to rural areas enhance small firms to utilize rural raw materials for production. Ekpenyong, (2005) in his study also found a positive association among community electrification and rural growth. The literature on community infrastructural development also reveals that where adequate electricity is available, many economic activities and perhaps industrialization spring forth. Nyong, (2003) confirms this proposition when he contends that adequate supply of energy is the basis of industrial revolution. Also there is a consensus among researchers that infrastructure generally impact the growth of a community, Abosedra et.al (2009), Mandel (2008), Pendse (1980). For instance, water is essential for economic growth of a community particularly through its use for local manufacturing (Nandy \& Gordon, 2009). Same goes for electricity (Abosedra et.al 2009).

It should be pointed out here that government is for the most part in charge of enhancing social infrastructure through different income sources. The State is also responsible for welfare services to citizens (Adejumobi, 2004). But the Nigerian State is replete with inadequate social infrastructure. These include non-availability or regular supply of electricity, lack of or shortage of pipe borne water, educational institutions, poorly equipped or non-existent health facilities and so on. Thus, it can be rightly said that the Nigerian State has failed in this traditional role to provide adequate social infrastructure to its citizens. Iwayemi, (2008) paints the gloomy picture of Nigerian electricity situation and states that as far back as three decades, inefficient and no quality access to power has been a consistent component in Nigeria. This state of affairs has not changed, till today. Presently, Nigeria needs about 20,000 megawatts of electricity but less than 4000 megawatts is generated. Thus, it can be safely said that social infrastructure generally promotes development of a society and this in turn positively impacts on poverty reduction in such society.

\subsection{Joint Participation Strategy}

In the past, the Nigerian state has been the independent and predominant supplier of infrastructural funds. The ability of Nigeria to provide resources for infrastructure faced major problems in the mid-1980s when Nigerian economy was hit with an extreme monetary emergency coming full circle in the famous Structural Adjustment Program (SAP). Under the SAP administration, the State was required to separate itself from social administration services delivery, including basic provisioning of certain social services that had effect on the economy. According to Estahani (2005), such an economy cannot build human capital or attract skilled manpower. It is even worse today, given the cash crunch that characterizes the current global economic crisis and developing countries, in particular, have become the worst hit by the global crisis partly because of the underdeveloped nature of their economies, and as such have devised alternative sources of infrastructure funding. According to Sampson, (2008) joint participation initiative is one of the options of accessing funds for infrastructural development.

Ikeji, (2003) describes the joint participation strategy as integrative or co-operative strategy. 
He maintains that the major element in this approach is that rural development is viewed as a joint business of government and community. Effective co-operation between these two actors is the key philosophy and driving force of the strategy. This is to say that government goes into partnership or mutual participatory arrangement with the people, that is, planning and working with the people. Both the government and the communities are involved in the policy making, policy implementation (including mobilization of resources and the use of government and community development agencies) policy monitoring and evaluation, and policy dividend sharing (in terms of outcomes).

This scholar in the field, who describes this approach as the integrative/co-operative strategy says that the strategy socializes the policy making-process, implementation and monitoring/evaluation. Socializing the policy process implies participation of communities at all levels of rural development and policies/programmes implementation. The utility of this approach according to him, had long been recognized as an essential ingredient to the envisaged success of development policies, even though official response in this regard had been sadly poor over the years. It thus becomes imperative that community involvement in rural development policy process should ideally feature at every stage. He concludes that this strategy is non-interventionist, non-authoritarian and non-prescriptive and is stripped of encumbrances such as poor planning, conservation and ignorance of dynamics of modernization associated with community-led strategy. Proper political will and sincerity on the part of government, no doubt, is a critical element in the scheme called integrative/co-operative strategy considered to be inevitable for successful implementation of rural development policies.

\subsection{Theoretical Foundation}

Two major theoretical frameworks are examined in this work, namely: Basic Needs Theory and Participatory Theory. The Basic Needs Theory or Theory of Development was an outgrowth of the World Employment Conference of 1976 organized by the International Labour Organization (ILO). To the extent that this conference was organized by an organization whose preoccupation is with employment and increased productivity of labour. The Basic needs theory (or approach) can be conveniently classified along with known economic approaches to development.

The basic needs theory was developed by the ILO as a result of the failure and theoretical bankruptcy and empirical invalidity of the classical liberal theory with its accompanying "trickling down" cost and benefit effects which only passes on to the poor, while poverty, unemployment and the lack of social services among other socio-economic vices continue to rage unabated. The basic human needs strategy was supposed to address the question of absolute poverty by paying attention to the poorest lot in the society. Secondly, it was to address the issue of laying the basic infrastructures so as to place nearly all "ruralities" on an approximate and equal pedestal or spring board from where they could launch themselves into the orbit of development (Ekong, 1991). The features of the basic needs theory according to Streeten and Burki, (1978), include the following:

- High need or significant weight to meeting the particular needs of the poorest. 
- Stress on the significance of effort to change supreme hardship.

- Emphasis on supply administration particularly for the traditional administration.

- Emphasis on the need to restructure the institutional and political structure.

- The real meaning of basic necessities

- An implication for a need to restrict the exercise of consumers demand or artificial stimulation of wants in the face of initially very uneven income distribution.

The above features therefore place the concern of the basic needs approach beyond a concern for the alleviation of just absolute poverty but also for doing so in an integrated manner for an effective action. The basic needs theory judged from its features as stated above, tends to be founded on some theoretical assumptions according to Ekong, (1991) which could be identified as follows:

- That people are poor because they lack basic needs and that the provision of basic social services like water, light, food and so on, will remove or lay the foundation for alleviating poverty. This assumption is very closely akin to the one which says that people are poor because they have been "left out of the development process". Basic needs are therefore regarded as the way of widening the development process to include the poor.

- That there is harmony of interest and consensus of values in developing societies and that political leaders will act altruistically to provide basic needs to their poor masses.

- That, even if the leaders were altruistic in their dispensation, they should develop the economy in their domain to have the wherewithal to supply basic needs to their poor masses.

- That, with the provision of basic needs, the process of development will automatically take off and be sustained.

The basic needs approach in this context strongly underscores the need to accurately understand and analyze the social, political and economic environment concerned. Basic needs theory assumes that at the heart of every development programme there is a recognized need. Until there is an appreciation of the need, it is very difficult if not impossible to get a sustainable development programme underway and without sustainable infrastructural development there can be no poverty alleviation in any society. This theory therefore implies that the policy of development project even in emergency situation should encourage grassroots mobilization and popular participation. The theory is relevant to this study and it is also important in poverty eradication studies since it has to do with the satisfaction of essential desires of the deprived in the third world nations. The major task of this study is to examine the joint participation synergy between state and community based organizations in poverty alleviation as it affects provision of infrastructure in local communities of Akwa Ibom State. Thus, the theoretical framework of basic needs theory is consistent with the problem statement and hypotheses of this study in that the dire demand of infrastructural facilities in the local communities of Akwa Ibom State should be pursued, approached and resolved on the basis of the basic needs theory for effect. However, a more closely knit and related, and even more appropriate theoretical framework chosen for this work is the 
Participatory Development Theory because the central-focus of this study is joint participatory development approach to community development and poverty alleviation.

The choice of this particular theoretical framework is predicated on the researchers emphasis on the state and community joint participatory strategy as a vehicle or means for providing the basic social needs through the enhancement of infrastructural facilities such as water and electricity, skill acquisition, education and health facilities among others to the rural communities in Akwa Ibom State for purposes of reducing poverty in these communities. The Participatory Development Approach in whatever form has been described by various names such as popular participation, participatory rapid appraisal, participatory rural appraisal and participatory action research. The participatory development approach originated in the late 1970's in Chang Mai and Kohn Kean Universities in Thailand. Participatory development theory has had better awareness since the 1970's, when it became out of the sympathy strategy toward addressing essential needs of the deprived in the society (Micherner, 1998). Participatory action research emerged due to failure of earlier development methods built on the "stream flowing down" or top-down principles.

With the unrealistic nature of transfer of technology, researchers and development experts started appreciating the perplexing association between the society, financial aspects and legislative issues in rural areas. As indicated by Rahman (1981), the fundamental belief system of the Participatory Action Research (PAR) is that the rural populace, the individuals who are socio-economically deprived, will logically change their surroundings by their own particular praxis. Others can only play roles such as facilitators, from the government to NGO's or other professionals who are only to act as catalyst or play a supporting role, and not to dominate. In this way, participatory action research (PAR) seeks to eliminate previous efforts at development of the rural areas, which were characterized by a predominant dominating relationship, irrespective of whoever sponsored the development effort. It places emphasis on people's initiatives to seek to improve their own conditions, in the generation of indigenous knowledge to complement professional knowledge, which take off from their traditional culture and seeks to preserve the physical environment which they have an organic association (Rahman, 1981). PAR's major objectives are to empower the poor to be self-reliant and free.

In the area of poverty alleviation specifically and going through the literature, this work has identified the yawning gap in relation to the duration and sustenance of poverty alleviation projects and programmes provided to rural communities. In the first place these projects and programmes are fed on the rural masses as pills to remedy their poverty ailment. It is one thing to take the cow to the water and it is another thing to get the cow to drink the water. In effect most of those projects and programmes fail at implementation stage as a result of none involvement of the rural target beneficiaries. The people are not interested in the execution of such projects and programmes. This is the reason we have so many NDDC and government abandoned water works and electricity projects scattered in almost all the local communities of Akwa Ibom State. The PAR approach adopted in this work from all its assumptions has shown that if the people, the target beneficiaries of those projects were involved from the outset, that is from policy enunciation through the physical execution and implementation of 
such community projects, there would have been no room for abandonment of the projects.

Moreover when the people manage their projects, the duration for completion of the projects is shortened and there is sustainability of the projects. Community projects provided through joint participation of the state and CBOs and managed by the communities are not vandalized as in the case of government installations erected in such communities without the involvement of the local inhabitants. The state and CBOs joint collaboration approach provides the enabling environment to the local communities to take remedial measures to sustain community projects established in their localities ever before government intervention. For instance it is very common to see local communities using local raw materials to sustain broken down electric poles before government intervention to rectify the damage. Therefore this work provides the panacea for the members of the rural communities to be involved and empowered to participate in every phase of their community development process.

\section{Main Objectives of This Research and the Hypothesis}

\subsection{Objectives}

The research sought to find out the relationship that exists between joint participation of the State and CBOs in the provision of social infrastructure and poverty alleviation. Specifically, the study sought to:

i. Examine whether the provision of electricity in rural communities of Akwa Ibom State significantly relates to poverty alleviation.

ii. Examine whether skill acquisition facilities in rural communities of Akwa Ibom State significantly relates to poverty alleviation.

iii. Examine whether joint participation between the State and CBOs in social infrastructural development in the rural communities of Akwa Ibom State significantly relates to poverty alleviation.

\subsection{Research Hypotheses}

$\mathrm{Ho}_{1}$ There is no significant relationship between the provision of electricity and poverty alleviation in rural communities of Akwa Ibom State.

$\mathrm{Ho}_{2}$ There is no significant relationship between the provision of skill acquisition facilities and poverty alleviation in rural communities of Akwa Ibom State.

$\mathrm{Ho}_{3}$ There is no significant relationship between joint participation of State and CBOs in social infrastructural development and poverty alleviation.

\section{Research Methodology}

The study adopted survey research design, whereby a cross-sectional survey approach was adopted towards ascertaining the existence of the concept of joint participation of the state and community based organizations (CBOs) and its contribution in the provision of infrastructural facilities such as potable water, power supplies and skill acquisition facilities vis-a-vis their impact on poverty reduction in Akwa Ibom State. The study population 
comprises all adult persons or working and non-working class, of different gender, educational and religious categories, and who also constitute the over 3.9 million people in the State according to National census figure (National Population Commission, 2006). A mixture of simple random sampling and multi stage cluster sampling techniques was used in determining a sample size of 600 respondents. Data collected for the study were analyzed using simple percentage and Chi-square $\left(\mathrm{X}^{2}\right)$ test was used for hypotheses testing.

\section{Research Analysis and Results}

Table 1. Relationship between provision of electricity supply in local communities of Akwa Ibom State and poverty alleviation

\begin{tabular}{lllll}
\hline $\begin{array}{c}\text { Provision of electricity } \\
\text { supply through joint } \\
\text { participation }\end{array}$ & \multicolumn{1}{c}{$\begin{array}{c}\text { Enhances poverty } \\
\text { alleviation }\end{array}$} & $\begin{array}{c}\text { Does not } \\
\text { enhance } \\
\text { poverty } \\
\text { alleviation }\end{array}$ & Total \\
\hline Where provided & $300(50$ percent $)$ & $56(9.3$ percent $)$ & 356 & 59.3 percent \\
Where not provided & $220(36.7$ percent $)$ & $24(4$ percent $)$ & 244 & 40.7 percent \\
Total & $520(86.7$ percent $)$ & $80(13.3$ percent $)$ & 600 & 100 percent \\
\hline
\end{tabular}

Result of chi-Square Test for Hypothesis No.1:

Degree of freedom $(\mathrm{d} / \mathrm{f}) \quad=1$

Level of significance $\quad=0.05$

Calculated $\left(\mathrm{X}^{2}\right)$ value $=4.31$

Table $\left(\mathrm{X}^{2}\right)$ value $\quad=\quad 3.84$

Table 1 presents the relationship between provision of electricity supply in local communities of Akwa Ibom State and poverty alleviation

From the calculation, the tabulated $\left(\mathrm{X}^{2}\right)$ value is 3.84 and the calculated $\mathrm{X}^{2}$ value is 4.31 . Therefore, the null hypothesis which states that there is no significant relationship between the provision of electricity supply in local communities of Akwa Ibom State and poverty alleviation is rejected and alternative hypothesis is accepted. The result showed that there is significant association between the provision of electricity supply in local communities of Akwa Ibom State through joint participation of State and CBOs and poverty alleviation in such communities. This means that the provision of electricity supply through joint participation of the State and CBOs in Akwa Ibom State has impacted positively on poverty alleviation in the State.

Furthermore, using the contingency correlation coefficient formula, the chi-square statistics here yielded a correlation of 0.08 between the variables, thus, there is a strong correlation between the provision of electricity supply in local communities of Akwa Ibom State and poverty alleviation in such communities 
Table 2. Relationship between provision of skill acquisition facilities in local communities of Akwa Ibom State and poverty alleviation

\begin{tabular}{lllll}
\hline $\begin{array}{c}\text { Provision of electricity } \\
\text { supply infrastructure joint } \\
\text { participation }\end{array}$ & $\begin{array}{c}\text { Enhances poverty } \\
\text { alleviation }\end{array}$ & $\begin{array}{c}\text { Does not enhance } \\
\text { poverty alleviation }\end{array}$ & Total \\
\hline Where provided & $238(39.7$ percent $)$ & $72(12$ percent $)$ & 310 & 51.7 percent \\
Where not provided & $200(33.3$ percent $)$ & $90(15$ percent $)$ & 290 & 48.3 percent \\
Total & $438(73$ percent $)$ & $162(27$ percent $)$ & 600 & 100 percent \\
\hline
\end{tabular}

Result of chi-square test for Hypothesis No. 2

Degree of freedom $(d / f) \quad=1$

Level of significance $\quad=0.05$

Calculated $\left(X^{2}\right)$ value $\quad=4.5$

Table $\left(X^{2}\right)$ value $\quad=3.84$

Table 2 presents the relationship between provision of skill acquisition facilities in local communities of Akwa Ibom State and poverty alleviation.

From the calculation, the tabulated $\left(X^{2}\right)$ value is 3.84 and the calculated $X^{2}$ value is 4.5 . Therefore, the null hypothesis which states that there is no significant relationship between provision of skill acquisition facilities in local communities of Akwa Ibom State and poverty alleviation is rejected and alternative hypothesis is accepted. The result showed that there is significant association between provision of skill acquisition facilities in local communities of Akwa Ibom State through joint participation of the state and CBOs and poverty alleviation in such communities. This mean that provision of skill acquisition facilities through joint participation of the state and CBOs in Akwa Ibom State has impacted positively on poverty alleviation in the State.

Furthermore, using the contingency correlation coefficient the chi-square statistics here yielded a correlation of 0.08 between the variables, thus, there is a strong correlation between the provision of skill acquisition facilities in local communities of Akwa Ibom State and poverty alleviation in such communities. 


\section{Macrothink}

Journal of Public Administration and Governance

ISSN 2161-7104

2021, Vol. 11, No. 4

Table 3. Relationship between joint participation of state and community based organizations in infrastructural development and poverty alleviation

\begin{tabular}{lcccc}
\hline $\begin{array}{c}\text { State and community } \\
\text { joint participation }\end{array}$ & $\begin{array}{c}\text { Enhances poverty } \\
\text { alleviation }\end{array}$ & $\begin{array}{c}\text { Does not } \\
\text { enhance poverty } \\
\text { alleviation }\end{array}$ & \multicolumn{2}{c}{ Total } \\
\hline & $270(45$ percent $)$ & $60(10$ percent $)$ & 330 & 55 \\
Non-joint participation & $200(33$ percent $)$ & $70(11.6$ percent $)$ & 270 & 45 \\
Total & $470(78$ percent $)$ & $130(22$ percent $)$ & 600 & 100 \\
\hline
\end{tabular}

Result of chi-square test for Hypothesis No. 3:

Degree of freedom $(d / f)=1$

Level of significance $=0.05$

Calculated $\left(X^{2}\right)$ value $=5.23$

Table $\left(X^{2}\right)$ value $=3.84$

Table 3 presents the relationship between joint participation of state and community based organizations in infrastructural development and poverty alleviation.

From the calculation, we can see that the tabulated $\left(X^{2}\right)$ value is 3.84 and the calculated value is 5.23. Therefore, the null hypothesis which states that there is no significant relationship between joint participation of the state and community Based Organizations in infrastructural development and poverty alleviation in Akwa Ibom State is rejected and the alternative hypothesis is accepted. A critical look at Table 3 shows that there is a significant association between Joint Participation of the State and Community Based Organizations in infrastructural development and poverty alleviation in Akwa Ibom State. In other words, joint participation between the State and CBOs in the provision of social infrastructural facilities has impacted positively on poverty alleviation in Akwa Ibom State, particularly where the joint participation approach is employed to provide social infrastructure such as water and electricity schemes, skill acquisition, health facilities and education facilities for the overall community development in the State.

Furthermore, using contingency correlation coefficient formula, the chi-square statistics yielded a correlation of 0.09 between the variables, thus, hence there is a strong correlation between joint participation of the State and CBOs and poverty alleviation in Akwa Ibom State.

\section{Discussion}

The under listed findings are based on the result of the test of hypotheses in this work. The analysis of data has been quite revealing in the sense that certain salient results were brought out. But suffice it to state that generally the study reveals that most of the development 
projects such as infrastructures found in Akwa Ibom State Rural Communities, for example rural water and electricity supply schemes, schools, health centres and cottage hospitals, market stalls, oil processing mills, handicraft centres and even feeder roads were found to have been established through joint participation between the State and the rural communities acting through community groups and associations generally referred to as Community Based Organizations (CBOs). These organizations act as mediators, pressure groups and in some cases as the originating actors in social policy administration process. They take into consideration the impoverished nature of their communities and the poverty profile of the people in their communities and they exert substantial influence on the other actors in social policy arena particularly the State for the betterment of the condition of living in those communities. They join or partner with the State and non-State actors to bring about socio economic development in these communities.

These organizations see development of their communities as a procedure which includes proper appreciation of key challenges in their communities. They see the process as one of the vital steps aimed at addressing the rural issues.

\section{Specific Findings}

First, the study shows that there is significant relationship between joint participation of the state and community based organizations (CBOs) in infrastructural development and the poverty alleviation in Akwa Ibom State. This is shown in the analysis in Table 3 where the null hypothesis which states that there is no significant association between joint participation of the State and community based organizations (CBOs) in the provision of social infrastructure and poverty alleviation in Akwa Ibom State, which was rejected in the study for the alternative hypothesis. This strategy was found to be very crucial to poverty alleviation in local communities of Akwa Ibom particularly in the area of social infrastructural facilities. The strategy readily lends itself as a useful social engineering process or mechanism in the hands of these two actors having the desire to make a meaningful impact on poverty alleviation in rural communities in Akwa Ibom State. Joint participation between the state and community based organizations in the initiation and execution of social infrastructure was found to be the necessary bedrock for poverty alleviation in Akwa Ibom State. This study shows that by adopting the joint participation approach, there are added advantages which accrue to policy administration process, particularly in social policy administration arena which traditionally involves policy adoption, enunciation, implementation and evaluation. These advantages include the use of the self-help component as well as other local components in the local communities for implementation of government policies and programmes on poverty alleviation as it relates to the provision of social infrastructural facilities. Here local materials and human capital are harnessed and put into use, the citizenry is educated about the programmes and they build commitment for their use and maintenance from there. Past successes with self-help projects in rural communities of Akwa Ibom State was also found to have made the joint participation between States and CBOs possible.

Second, the study uncovers that the participatory or integrative and co-operative model of community development symbolized in the joint participation approach of the state and 
community based organizations (CBOs) is quantitatively superior to the independent government-led and community-led approaches, and that it ensures the coming together of all actors, government and non-governmental on the one hand and community based organizations (CBOs) on the other in the policy process.

Third, the study reveals that the past policies and programmes were bedeviled by an array of development - inhibiting problems including:

i. Lack of effective participation by the people in policy process as a major obstacles to success.

ii. Inadequacy of development and organizational capacity on the part of the local communities.

iii. The fact that community self-help has been characterized by haphazard, uncoordinated and laisez fair pursuits leading to wasteful duplication of scarce energies and resources.

Fourth, the study reveals that the joint participation strategy enhances social infrastructural development projects and programmes in local communities of Akwa Ibom State and that this also impacted positively on poverty alleviation in the State as they resulted in the enhancement of the livelihood of members of the benefiting communities in the State through establishment of small scale enterprises in the local communities of the State. This view was expressed by majority of the respondents as recorded in their responses to the relevant research questions and this actually confirms the hypothesis that tested the relationship between the provision of electricity and skill acquisition facilities as graphic examples of the usefulness of social infrastructure for poverty alleviation in local communities of Akwa Ibom State. Joint participation of the two actors in the study manifested in the increased provision of rural water and electricity supply works, skill acquisition, education and health care facilities, and many others.

Fifth, the study reveals that improved and increased social infrastructural facilities through joint participation strategy has led to a rise in job opportunities in Akwa Ibom State communities and this in turn led to increase in income earning of the people in such communities. The overall impact was found to be a general reduction in the poverty level within the communities investigated.

Sixth, the study reveals that, for sustenance and maintenance of the community projects in the local communities, the benefiting communities which jointly participated with State to develop the infrastructural facilities in local communities of Akwa Ibom State also provided protection and maintenance of the projects after their successful completion.

Seven, the study unveils that, there are many agencies, ministries of government (responsibility centres) involved and overseeing community development in general and enhancement of infrastructural development in local communities in Akwa Ibom State which through the joint participation strategy can be made to network in tandem and function in close association with the community leaders and their various community based organizations (CBOs). This integrative and co-operative approach was found to have reduced 
to the barest minimum "official" or administrative bureaucracy and redtapism and even the usual conflicts and competition amongst these responsibility centres normally experienced in the government-led or top-down approach to community development.

Eight, social policies designed and implemented to incorporate and take into consideration the full participation and integration of the rural communities through the community leaders and their community based organizations (CBOs) in terms of articulation, enunciation, adoption and implementation of social programmes and projects ensures socio economic development of rural communities.

Ninth, and finally, this study could be replicated by the governments of Akwa Ibom State and Nigeria at large and even other State governments, in other local communities in the country.

\section{Conclusion}

From this study, it is evident that unlike previous rural development strategies for poverty alleviation in Akwa Ibom State, the joint participation strategy of the state and community based organizations (CBOs) has made some significant impact on poverty alleviation through well integrated social infrastructural development policies and programmes in the rural communities of Akwa Ibom State.

Social policy administration is the critical dimension in which an integrated infrastructural development can be achieved for poverty alleviation in Akwa Ibom State. Since the success or failure of any given strategy is, to a high level, a function of execution, there is therefore a need for implementation strategy or strategies that allow community participation in the growth of the local communities, particularly in the area of social infrastructural development in the State. The need is an urgent one and more desirable in the face of the general low quality of life of most dwellers of these rural communities. By so doing incidence of poverty in such rural communities would be drastically reduced and there would be visible improved conditions of life among the citizenry in such rural communities.

\section{Recommendations}

The study recommends that the governments of Nigeria and Akwa Ibom State of Nigeria should develop policies that would involve and integrate the people and their CBOs in the development of rural communities in Nigeria at large and Akwa Ibom State, in particular, in terms of social infrastructural development, for purposes of poverty alleviation in the country and Akwa Ibom State respectively.

\section{References}

Abasiekong, E. (1999). Community organization and development in Nigeria. Uyo: Dorand Publishers.

Abosedra, S., Dah, A., \& Ghosh, S. (2009). Electricity consumption and economic growth: The case of Lebanon. Journal of Applied Energy, 86(4), 104-113.

Abumere, S. I., Okafor, S. I., \& Oluwasola, O. (2002). Rural infrastructure and the development process in rural Nigeria. Ibadan: Development Policy Centre Press. 
Adams, C., \& Bell, M. (1999), Community partnership grant making and emerging local democracies. Paper presented at the 1999 Association of Public Policy Analysis and Management Research Conference, Washington DC.

Adeboyejo, A. T (2006). Local institutions and infrastructure development in Ogbomoso, Nigeria. A Paper Presented at the International Conference on Infrastructure Development and the Environment (ICIDEN) Abuja, Nigeria.

Adejumbi, S. (2004). Economic globalization, market reforms and social welfare services in West Africa. Darker: CODESRIA Press.

Agbor, C. O. (2006). The role of forest product in sustainable rural livelihood. In F. Bisong (Eds). Natural resources, use and conservation systems for sustainable rural development. Calabar: BAAJ International.

Aguda, A. S. (1998). The home town association as a community development agent. In Honey R \& S. Okafor (Eds). Home town associations. Ibadan: Sam Bookman Publisher.

Agunbiade, B. (1998). The changing roles of home town association in community development: The fiditi progressive union. In Honey, R \& Okafor, S. (Eds). Home town associations. Ibadan: Sam Bookman Publisher.

Ajibesin, K. (2012). Ethnobotanical survey of Akwa Ibom State of Nigeria. Journal of Ethnophamacology, 20(8), 80-92.

Ake, C. (1996). Democracy and development in Africa. Ibadan: spectrum books.

Akinola, S. R. (1997). The impact of rural roads on physical development in Ife region, Osun State, Nigeria. An Unpublished Ph.D Thesis Department of Urban and Regional Planning, Ile Ife Obafemi Awolowo University, Press.

Akpama, S. I. (2005). Grassroots participation in community development. A study of selected infrastructures. Unpublished B.Sc Project, Department of Sociology, University of Port Harcourt.

AK-SEEDS. (2005). Akwa Ibom State economic empowerment development strategy report document. Uyo: Ministry of Economic Development.

Aliu, A. (2001). National poverty eradication programme (NAPEP) completion implementation, coordination and monitoring. Abuja: NAPEP Publication.

Aluko, S. (1995). Poverty reduction: Learning the lessons of experience: Finance and Development, 31(3), 107-123.

Anikpo, M. (1984). The peasantry and the dilemma of underdevelopment in Nigeria. Pan Africa Social Science Review, 1(1), 24-37.

Barkan, D., Michael M., \& Ayemi, M. O. A. (1991). Home town voluntary association, local development and the emergence of civil society in western Nigeria. The Journal of Modern Africa Studies, 29(3), 67-82. 


\section{Macrothink}

Journal of Public Administration and Governance ISSN 2161-7104 2021, Vol. 11, No. 4

Bhalla (2000). Evaluation of infrastructural interventions for poverty alleviation. New Delhi: Institute of Transport Development Press.

Burky, S. (1993). People first: A guide to self-reliant participatory rural development. London: Zed Books.

CASSAD, (1992a) Community associations and development in Nigerian urban centres. Ibadan: Centre for African Settlement Studies and Development.

CASSAD (1992b) Community based associations as vehicles for socio-economic development in Nigeria. Retrieved from https//www,CASSADmonographic.cm/series/85495. Visited on 21/1/2014.

Chambers, R. (1983). Rural development: Putting the last first. London: Longman.

Chino, T. (2004). Oil for nothing: Multinational corporations, environmental destruction, death and impunity in the Niger Delta. United State of America Non-Governmental Delegation Trip Report, 6(12),17-28.

Donald, C. S. (1972). Professional education in public works/environmental engineering administration. Chicago: America Public Works Association.

Ebong, M. O. (1991). Mobilization of resources for rural development in Nigeria. Calabar: Wusen Press.

Edame, G. (2005). Development economics and planning in Nigeria. Calabar: Ojies Production.

Egun, A. (2010). The changing face of agricultural education in Nigeria: Challenges and prospect. Retrieved from www.educationwinter.com/645753e987

Ekong, E. E. (1984). Rural development indices for measuring the quality of life in rural Nigeria. Nigerian Journal of Rural Sociology, 1(1), 45-58.

Ekong, E. E. (1991). Rural development and the persistence of poverty: UNICROSS Inaugural Lecture Series, 4, 12-19.

Ekpenyong, E. (2005). Perspectives in community poverty alleviation. A Newsletter of NGO Coalition on Environment, 21(3), 51-71.

Emmanuel, T. A., \& Muili, A. B. (2008). Research paper on constraints militating against effectiveness of community development projects in Ilesa. Retrieved www.academicjournals.org. Visited 15/5/2013.

Estahani, S. (2005). Measuring public sector performance in infrastructure. Washington: World Bank Press.

Esulan, M., \& Uphoff, N. (9184). Local organizations, intermediaries in rural development. Ithaca: Cornell University Press. 
Familoni K. A (2004). The role of economic and social infrastructure in economic development. A Global View: Proceedings of the $11^{\text {th }}$ Annual Conference of Zonal Research Unit, Lagos.

Fawehinmi, Y. (2003). Local government and infrastructural development in Nigeria. In Fawehinmi, Y (Eds). Urban finance and infrastructural development in Nigeria. Lagos: University of Lagos Press.

Frank, I. (2003). The state of urban infrastructure in Nigeria. In Fawehinmi, Y. (Eds). Urban Finance and Infrastructural Development in Nigeria. Lagos: University of Lagos Press.

Fred, C. (2007). Strategies for community development in Ilesa Nigeria. Illinois. Peacock Publishers.

Hammer, L., Booth D., \& Lovell, E. (2000). Poverty and transport: A report prepared for the World Bank in collaboration with DFID, overseas development institute. Washington: World Bank Publication.

Hesselbein, F., Goldsmith, M., Beckhard, R. \& Schubert, R. (1998). The community of the future. San Francisco: Jossey Bass

Huntington, S. P. (1968). Political order in changing societies. London: Yale University Press

Idachaba (1985): Rural infrastructures in Nigeria. Federal department of rural development. Ibadan: University of Ibadan Press.

Ikeji, C. C. (2003). Strategies for effective implementation of rural development policies in Nigeria: The integrative/co-operative model. Global Journal of Social Sciences, 2(1), 98-113.

Ikeji, C. C., \& Ataide, H. O. (2006). A reconsideration of some theoretical and empirical issues in social policy administration: Focus on the role of CBOs in poverty alleviation in Itu Local Government Area. Journal of Policy and Administrative Studies, 1(2), 34-56

Ikporukpo, C. (1998). Development and territoriality of home town associations: The Odimodi Ebidou Bene of the Niger Delta region of Nigeria. In Honey, R \& Okafor, S (Eds). Home town associations. Ibadan: Sam Bookman Publisher.

Iwayemi, A. (2008). Investment in electricity generation and transmission in Nigeria: Issues and options. In International Association for Energy Economics, 1(2), 45-52.

Kerr, G. B. (1978). Voluntary associations in West Africa: Hidden agent of social change. African Student Review, 10(4), 103-121.

Mandel, E. N. (2008). When to open infrastructure access. Ecology Law Quarterly, 35(2), 40-57.

Mark, L., \& Titilola, T. (1998). Home town associations as development catalysts. In Honey, R. \& Okafor, S. (Eds). Home town associations. Ibadan: Sam Bookman Publishers 
Micherner, V. J. (1998). The participatory approach: Contradiction and co-option in Burkina Faso. In Graswell, J. L (Eds). World Economic Development, 26(12), 67-83.

Midgley, J. H., Haidiman, M. E., \& Narine, D. (2003). Community participation, social development and state. London: Methuen.

Nandy, S., \& Gordon, D. (2009). Children living in squalor: Shelter, water and sanitation deprivations in developing countries. Children, Youth and Environment Review, 19(2), 71-83.

Nigerian National Bureau of Statistics (NBS) (2020). "2019 Poverty and Inequality in Nigeria" Report, May 28, 2020. https://www.worldbank.org/en/programs/lsms visited on 6/7/2021.

National Population Commission (2006). Federal republic of Nigeria official gazette. Lagos: National Population Commission Press.

Ntui, O. E. (2005). Assessment of the level of community participation in rural development projects within the support zone of Cross River national park. Unpublished M.Sc Thesis, Faculty of Agriculture, University of Calabar.

Nyong, E. E. (2003). Creating an enabling environment for sustainable development of Niger Delta region. Paper Presented at a Workshop on Sustainable Development of the Niger Delta Region, Port Harcourt.

Obadan, M. I. (2002). Poverty reduction in Nigeria: The way forward. Ibadan: Nigeria Economic Society.

Obibuaku, L. G. (1993). Agricultural extension as a strategy for agricultural transformation. Nsukka: University of Nigeria Press.

Okereke, C. (2004). Sustainable development and poverty eradication in Third World. London: Routledge Publishers.

Okereke, O. O. (2003). Development administration in Nigeria: Issues and strategies. Owerri: Concave Publishers.

Oluwu, D., Ayo, S. B., \& Akande, B. (1991). Local institutions and national development in Nigeria. Ile-Ife: OAU Press.

Onokerhoraye, A., \& Okafor, S. (1981). Community development in action. Owerri: Image and Slogans.

Onuoha, B. C. (1999). The third world nations and underdevelopment: The role of some personality. Port Harcourt: Education Books and Investment.

Ostron, E. (1990). Governing the commons. The evolution of institutions for collective action. New York: Cambridge University Press.

Oyegoke, B. (1998). Civil society and participation: A case study of Egbe Omo-Ilu Okuku. In Honey, R \& Okafor, S., (Eds). Home town association. Ibadan: Sam Bookman Publishers. 
Peet, R., \& Watts, M. (1996). Liberation ecology: Development, sustainability, and environment in an age market triumphalism. In R. Peet \& M. Watts (Eds). Liberation ecologies, environment, development and social movements. London: Routledge.

Pendse, D. R. (1980). Energy crisis and its impact on energy consumers in third world. Economic and Political Weekly, 15(4), 23-39.

Putnan. R. (1993). Making democracy work. New Jersey: Princeton University Press.

Rahman, M. A. (1981). Glimpses of the other Africa. In Fals-Borda, O., \& Rahman, M. (eds). Action and knowledge. London: Bogele Publication.

Roa, V., \& Wookock, M. (2003) Integrating qualitative and quantitative approaches in programme evaluation. Washington: World Bank.

Sampson, E. (2008). Global financial crisis: Recession, depression and other threats. Zenith Economic Quarterly, 3(4), 65-74.

Seers, D. (1970). The meaning of development. New York: Agricultural Development Council Press.

Sen, A. K. (1999). Development and freedom. New York: Knopf Press.

Strauss, L. (1953). Natural right and history. Chicago: University of Chicago Press.

Streeton, P., \& Burky, S. (1978). Basic needs: Some issues. World Development, 1(3), 20-33.

Tunrayo, A. T. (2009). Effect of community based organizations: Activities on poverty alleviation in Yewa South local government area of Ogun State, Nigeria. Pakistan Journal of Social Sciences, 6(6), 40-67.

Umoh, B. E. (1985). Community development in the Cross River State: Problems and prospects. Proceeding of the Nigerian Rural Sociological Association, Second Annual Conference, Uyo.

Warren, D, Slikkerveer, L. J., \& Brokensha, D. (1995), The cultural dimension of development. London: Intermediate Tecnology Publications.

Wimberly, R. C. (1993), Policy perspective on social, agriculture and rural sustainability. Journal of rural Sociology, 58, $107-118$.

United Kingdom Department for International Development (DFID) (2000). Nigeria country strategy. London: DFID Publications.

United Kingdom Department for International Development (DFID) (2001). Nigeria country strategy. London: DFID Publications.

World Bank (1994). World development report. Washington: World Bank Press

World Bank (1996). Nigeria: Poverty in the midst of plenty, the challenging of growth with inclusion. Washington: World Bank Press 


\section{Macrothink}

Journal of Public Administration and Governance ISSN 2161-7104

World Bank (2004). Making infrastructure work for the poor. Washington: World Bank Press.

World Bank (2006). Reducing poverty through growth and social policy. Washington: World Bank Press.

World Bank (2012). Poverty level report in developing country. Washington: World Bank Press.

\section{Copyright Disclaimer}

Copyright for this article is retained by the author(s), with first publication rights granted to the journal.

This is an open-access article distributed under the terms and conditions of the Creative Commons Attribution license (http://creativecommons.org/licenses/by/4.0/). 